Scientific Review - Engineering and Environmental Sciences (2019), 28 (3), 432-443

Sci. Rev. Eng. Env. Sci. (2019), 28 (3)

Przegląd Naukowy - Inżynieria i Kształtowanie Środowiska (2019), 28 (3), 432-443

Prz. Nauk. Inż. Kszt. Środ. (2019), 28 (3)

http://iks.pn.sggw.pl

DOI 10.22630/PNIKS.2019.28.3.40

\begin{abstract}
Anatoliy ROKOCHINSKIY ${ }^{1}$, Jerzy JEZNACH ${ }^{2}$, Pavlo VOLK ${ }^{1}$, Vasily TURCHENIUK $^{1}$, Nadia FROLENKOVA ${ }^{3}$, Roman KOPTIUK ${ }^{1}$

${ }^{1}$ Institute of Water and Environmental Engineering, National University of Water and Environmental Engineering

${ }^{2}$ Faculty of Civil and Environmental Engineering, Warsaw University of Life Sciences

- SGGW

${ }^{3}$ Institute of Economics and Management, National University of Water and Environmental

Engineering
\end{abstract}

\title{
Reclamation projects development improvement technology considering optimization of drained lands water regulation based on BIM
}

Key words: technology, projects, model, optimization, drained lands, water regulation

\section{Introduction}

Irrigation and drainage sector formed as an independent one in Ukraine in the last 35-40 years and is positioned on the intersection of environmental management, agriculture and hydrotechnical construction (Aydarov, Golovanov \& Nikolsky, 1990; Karuk, 1992; Rex, 1995; Shumakov, 1996; Romashchenko, Sobko, Savchuk \& Kulbida, 2003; Rokochinskiy, 2010; Rokochinskiy, 2016). The some problems we observed in Poland (Pierzgalski et al., 2012). The most intensive development of land reclamation in Ukraine occurred in 1966-
-1990 , but in 1991 the state capital investment in the water management sector in general and specifically in meliorative construction was sharply reduced. Gradually sharp decline over the years of construction and reconstruction of drainage systems and complete shutdown of their state funding occurred in 2002 (Rex, 1995).

This situation leads to inadequate supply of material and technical resources, fertilizers, lack of land improvement measures, disruptions in energy supply, reducing the amount of work on maintenance and repair of reclamation equipment, permanent loss of skilled personnel, incomplete use of scientific development, insufficient information support of farms and so on. Existing meliorative systems (MS), especially drainage, do 
not correspond to progressive demand of agricultural production, they are also obsolete outdated and require renovation and modernization. This shooed be corresponded to the National Program of Water Management and Environmental Rehabilitation of Dnieper river basin till 2020 and other standard legal acts which allow water melioration functioning.

In addition, today a very acute problem of climate change arises (Rokochinskiy et al., 2019). Therefore, a search for alternative ways of development of hydraulic variants of melioration, optimal types and designs of drainage systems, more efficient, reliable and environmentally friendly ways of reduction the material input, energy, funds, job, water capacity of agricultural production, also increase of food production and agricultural raw materials is an urgent position.

Reclamation development in Ukraine in, general, and particularly, in the drained area inherent all objectively common both as positive and negative trends. First of all, it concerns the fact, that the large-scale reclamation development requires significant investment, but the resulting economic effect of this is at least $60-70 \%$ from the project (Shumakov, 1996). Failure to achieve efficiency from reclamation project is due to lack of knowledge about the results of interaction of human reclamation activity with natural processes and taking them into account in the construction of reclamation facilities. Therefore, ways to improve drainage reclamation lies in the development and improvement of methods of optimization of design and calculation of drainage systems and their components on environmental and economic bases. In particular, transition to multivariance in the substantiation of design solutions is the search for the optimal design solution from selected possible alternatives. The main objective of comparative evaluation is to choose more economical and environmentally friendly investment options, that is, to ensure maximum impact from reclamation activities at the lowest cost for their realization (Shumakov, 1996).

As in previous years, and now, in practice, procedure of development of alternatives design solutions (DS) and selection of the best ones is absent, although in state building codes (SBS V. 2.4-1-99. Melioration systems and structures) fixed that the technical solutions as for schemes and structures of basic reclamation constructions should be taken on the comparison of key technical and economic indexes of different options. However, in practice, on the initial stage, after the necessary studies and research, project organization developed a technical draft of a project and later, it just clarifies, adds and substantiates its feasibility and effectiveness. Although the final choice of water regulation methods and their related type constructions and projects of MS can be done only considering technico-economical substantiation (TES) of optimal decisions by comparing their alternative variants (ways and projects of water regulation) on the object, which is under discussion.

\section{Materials and methods}

The need for this approach may be explained by the lack of reasonable and effective methods of research and selection of the optimal variant reclama- 
tion project. Therefore, substantiating design solution on environmental and economic basis needs improvement of the design process, especially when considering clarifying or drafting stages (Shumakov, 1996; Mazhayskiy, Rokochinskiy, Volchek, Meshyk \& Jeznach, 2017; Mioduszewski, Kowalewski, Zurawski \& Stankiewicz, 2010; Rokochinskiy, Volk, Pinchuk, Mendus \& Koptyuk, 2017).

Modern methodological basis and at the same time, universal technical tool that allows to improve the practice of designing complex objects and systems that is successfully used and developed in almost all fields of science, technology and industry is computer aided design -building information modelling - BIM (Rahman, Suwal \& Jäväjä, 2013; Juszczyk, Výskalab \& Zima, 2015).

In structural terms BIM is an organizational and technical system consisting of a large number of interrelated and interacting components. The main function of BIM is to carry out object aided design and their components through the use of mathematical models and other automated design procedures and computer technology (Mazhayskiy et al., 2017).

One of the major design goals is to find the optimal design solution from the chosen possible options. The essence of optimization thus is fixed on finding the best (possible) design decision based on climate, landscape, soil, geological, agronomic conditions, which gives the minimum (maximum) of some aimed function, that characterizes the overall (complexed) effectiveness of the designed object. So for the implementation of optimization the main requirement is to possess the alternatives, i.e. options totality of design decisions as for natural agro-reclamation conditions and formation of a real object terrain.

\section{Results and discussion}

Therefore, at the design stage of new construction or reconstruction of agricultural production system (APS) and hydromeliorative system (HS) according to design, technical, technological solutions (DS) are accepted only once (Mazhayskiy et al., 2017) and subsequent correction put in them the object management strategies according to changing weather conditions is impossible or impractical. Through practical inability to forecast the real nature of change within the design lifetime of the MS (30-50 years), this strategy can be implemented as follows.

Regarding the integrated optimization model the optimal DS in general can be defined as (Rokochinskiy, 2010; Mazhayskiy et al., 2017)

$$
\left\{\begin{array}{l}
U_{0}=\underset{\{i\}}{\operatorname{extr} U_{i}^{i}=\overline{1, n}_{i}} \\
Z_{0 j}=\min _{\{i\}}\left|Z_{j i}-\hat{Z}_{j}\right|, j=\overline{1, n_{j}} ; i=1, n_{i}
\end{array}\right.
$$

where:

$U_{0}$ - extreme values accepted by economic optimality criterion chosen $U$ corresponding to the optimum set for DS options $I=\{j\}, i=\overline{1, n_{i}}$;

$Z_{i j}-$ set $\{j\}, i=\overline{1, n_{j}}$ criteria (physical indicators) relevant ecological efficiency DS variants;

$\widehat{Z}_{j}$ - according to the accepted limiting environmental indicators. 
DS variants project set $I=\{j\}$, $i=\overline{1, n_{i}}$ composed by different technologies of drained land water regulation and appropriate design solutions on MS and their technical elements.

Then, as for to equation (1), the value criteria of economic and environmental optimization for each project solution, taking into account climatic management strategy in the long year period of the object is determined by the formulas:

$$
\begin{aligned}
U_{i} & =\sum_{p=1}^{n_{p}} u(I, P) \cdot \alpha_{p}, i=\overline{1, n_{i}} \\
Z_{j i} & =\sum_{p=1}^{n_{p}} z_{j}(I, P) \cdot \alpha_{p}, j=\overline{1, n_{j}}, i=\overline{1, n_{i}}
\end{aligned}
$$

Calculation base optimal level defines the parameters of the project design solutions of the specific object, it can be determined, unlike the accepted practice of rationing, also on environmental and economic grounds, taking into account existing natural and agro-reclamation conditions considering complex optimization model:

$$
\left\{\begin{array}{l}
p_{0}=\underset{\{p\}}{\operatorname{extr}} U_{0}(P), i=i_{0} ; p=\overline{1, n_{p}} \\
Z_{0 j}><\hat{Z}_{j}, j=\overline{1, n_{j}}
\end{array}\right.
$$

where:

$p_{0}$ - the typical optimal pattern of object climatic conditions considering calculation base of the growing season of a combination $\{p\}, p=\overline{1, n_{p}}$, which is defined by the extremum of the function $U_{0}(P)$ composed for economically optimal DS $i=i_{0}$;
$Z_{0 j}-$ set $\{j\}, j=\overline{1, n_{j}}$ criteria of environmental efficiency in $i=i_{0}$.

Realization of complex optimization models require definition of indicators and criteria of economic and environmental efficiency of DS which are formed, primarily, within the reclaimed field. Their integral evaluation by the number of fields with project or planned rotation in the structure of agricultural use system and based on technical elements of MS will help to characterize the ecological and economic effects for MS in general.

All components of the general optimization model, such as, technical and economic indicators (TEI), that make up the economic and mathematical models (investment, value obtained crop production, current agricultural and reclamation costs, etc.) as well as environmental indicators (criteria) water and general nature reclamation regimes of drained lands, are defined by accepted methods and water regulation schemes they are changeable and are dependent on many factors, the main of them are climatic, soil reclamation, agronomic and other object conditions. They can be schematically represented as baseline data for formulating and solving optimization problems due to multiple relevant indicators:

- meteorological stations or posts $\Omega=$ $=\{\omega\}, \omega=1, n_{\omega}$, Their shares $f_{\omega}$ or areas $F_{\omega}$ service within the system;

- drained soil types $G=\{g\}, g=\overline{1, n_{g}}$, heir shares $f_{g}$ or areas $F_{g}$ of dissemination;

- species of cultivated crops $Q=\{k\}$, $k=\overline{1, n_{k}}$, their shares $f_{k}$ or areas $F_{k}$ in the design crop rotation structure and their average calculated values (project or planning) yields $\bar{Y}_{k}, k=\overline{1, n_{k}}$ on drained lands; 
- possible ways of water regulation on drained lands $S=\{s\}, s=1, n_{s}$ and possible areas $f_{s}$ their usage within the system;

- calculated (typical) in terms of heat and moisture periods during the growing season $P=\{p\}, p=\overline{1, n_{p}}$ and their shares $\alpha_{p}, p=1, n_{p}$ within the designed lifetime of the system or the usage of drained land;

- structural elements of the system for the specific terrain, soil reclamation differences etc. $L=\{l\}, l=\overline{1, n_{l}}$ their shares $f_{l}$ or areas $F_{l}$ of dissemination;

- specific cost parameters for the determination of technical and economic indicators (TEI), which are part of the economic and mathematical models and so on.

Determining the required values of common optimization models components is possible only on the basis of solving complex and diversified, multiparametered, multifunctioned task using mathematical modeling computers and is based on creation the complex of hierarchical connected simulation submodels with forecasting on long-term basis of water and general reclamation nature modes of drained lands, their impact on the grown crops and created environmental impact.

Generalized structure of forecastsimulation and optimization calculations assessing the effectiveness of drained lands water regulation on the long term based due to various natural reclamation conditions is given in Figure 1.

Characteristic features implementation of designed structure is block construction. As well, it can be pointed out such relatively independent generalized units:
- data block of the initial data sets by major affecting nature-climatic, soil-reclamation and other factors (block 2, Fig. 1);

- block of forecast calculations on long-term basis based on a set of relevant models: meteorological regimes, water regime and water regulation technology, productivity of drained land for schematized natural agro-reclamation conditions of a real object (blocks 5, 8, 10, 12, Fig. 1);

- block of optimization calculations, which provides definition adopted in accordance with the structure of their operation (single or $n$-level), adopted criteria of economic and environmental efficiency of DS, that are considered according to the tasks formulated under accepted conditions of optimization as at the level of each reclaimed fields (grown culture), so as on the fields totality within the system (block 14, Fig. 1). Due to them general optimization condition and final selection of the management decision are implemented, which is done by informal way through expert assessment of the relevant expert at the design stage or routine operation of drainage systems, that take into account, on the one hand, economic efficiency, and on the other - environmental acceptability of its implementation (block 15, Fig. 1);

- block of formation and output of any intermediate (if required) and final results of forecast-optimization calculations at any stage of their execution (block 16, Fig.1).

Certainly, shown in Figure 1 general-purpose structure of forecasting, optimi- 




FIGURE 1. The generalized block-chart of forecast-optimization calculations with substantiation of design decisions on environmental and economic grounds

zation calculations will vary in each case of its application depending on the optimization problem level that is solved, and accepted for consideration according to formulated task, leveled structure of their implementation and specific nature conditions and other reclamation facility management.

Practical realization of forecast-imitation major amount and optimization calculation is possible only by using corresponding fools, which corresponds to BIM. 
So, for all the characteristic features, BIM refers to complex systems and methodological basis of its establishment and operation, as when creating a forecastoptimization methods and models are: system approach and system analysis.

Therefore, according to (Shumakov, 1996) the overall technology design of complex objects, processes and systems on a multiple basis at principle stages of their development can be represented as a block diagram (Fig. 1). This model illustrates general principles and approaches to the process of ecological and economic assessment of alternatives reclamation projects of construction and reconstruction, having the choice of optimal substantiative investment in the future (Fig. 2).

This model illustrates general principles and approaches to the process of ecological and economic assessment of reclamation projects construction and reconstruction alternatives, having the choice of optimal investment and its substantiation. Consider the basic steps in detail.

The given chart depicts the principles of transition from traditional mostly multivariate approach to substation of DS in creation of water melioration objects, to possible transition on optimization methods choosing DS optimal an multivariate base.

Considering all this, corresponding to modern demands, it is necessary to do ecology-economic evaluation of meliorative project, general model of which is given on (Fig. 3).

Its implementations include the following studies:

- Design initiation involves, primarily, the formation of idea and goal of the project, setting goals, forming its main characteristics and preliminary feasibility assessment of investments for its implementation.

- Design searching project. At the search pre-project stage collection and analysis of the necessary data are conducted, survey project works are carried out and, necessary studies to further definition of technical solutions possible options, thus to select the most economically and environmentally sound.

- Identification of DS potential options. An essential principle of reclamation design effectiveness and optimization is multi-variants of examined DS, aiming to select the best of them.

\section{Conclusions}

The main condition to implement optimization is to have alternatives, i.e. the set of all possible variants of design decisions considering possible variable nature agro-reclamation conditions of the real object. When designing reclamation activities as a rule, considerable number of different technical and technological solution options appear, that, accordingly, affect the economic and environmental efficiency from their implementation.

It is necessary to substantiate and determine the optimal design solution of the type, construction and parameters of reclamation system which are accepted by taken water regulation mode (scheme) on the system, considering existing natural and economic conditions. Therefore, at this stage all potential options of the project are examined to make a decision 


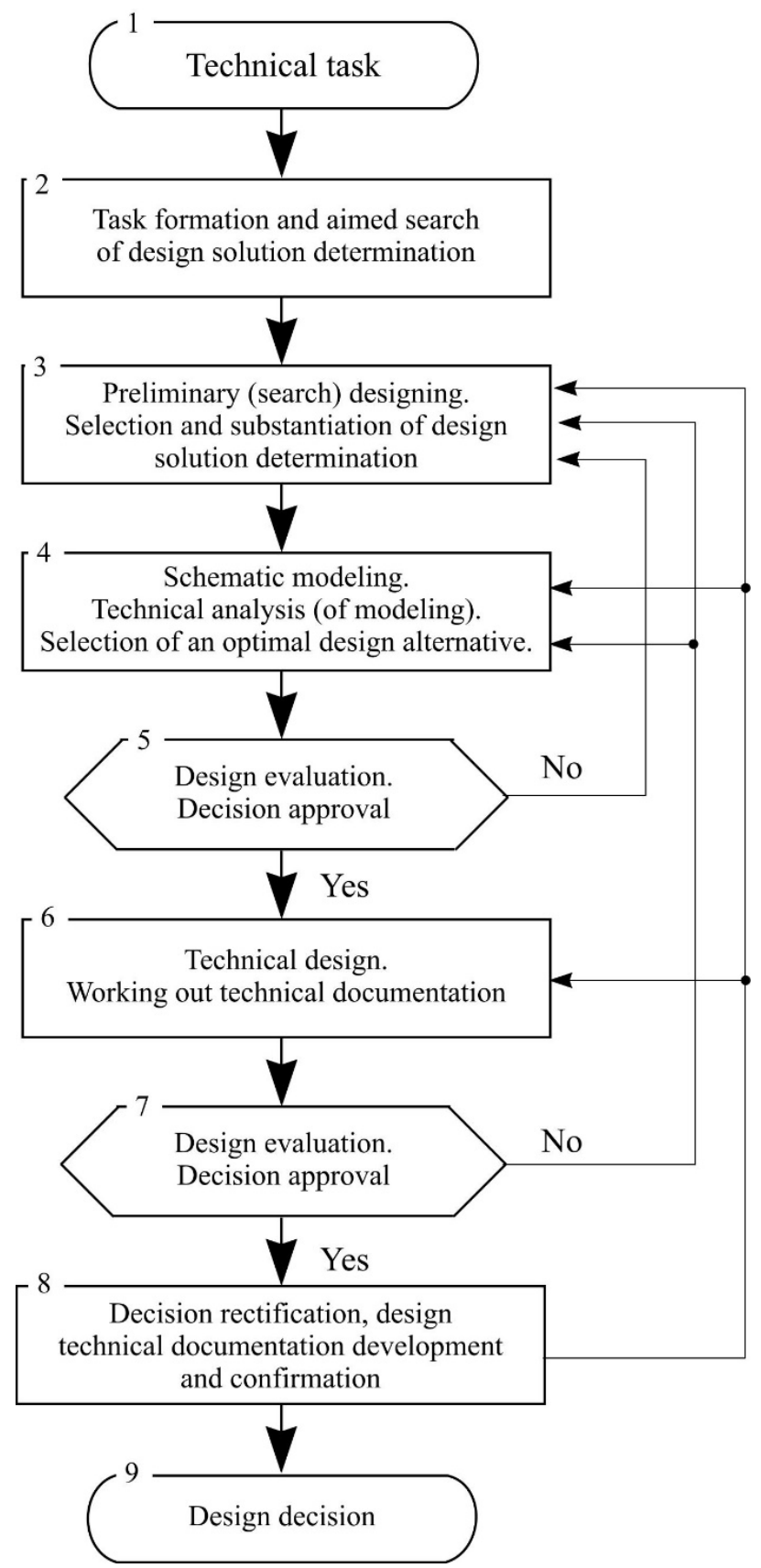

FIGURE 2. Typical logic chart of design process on a multiple basis by the principle design procedures 


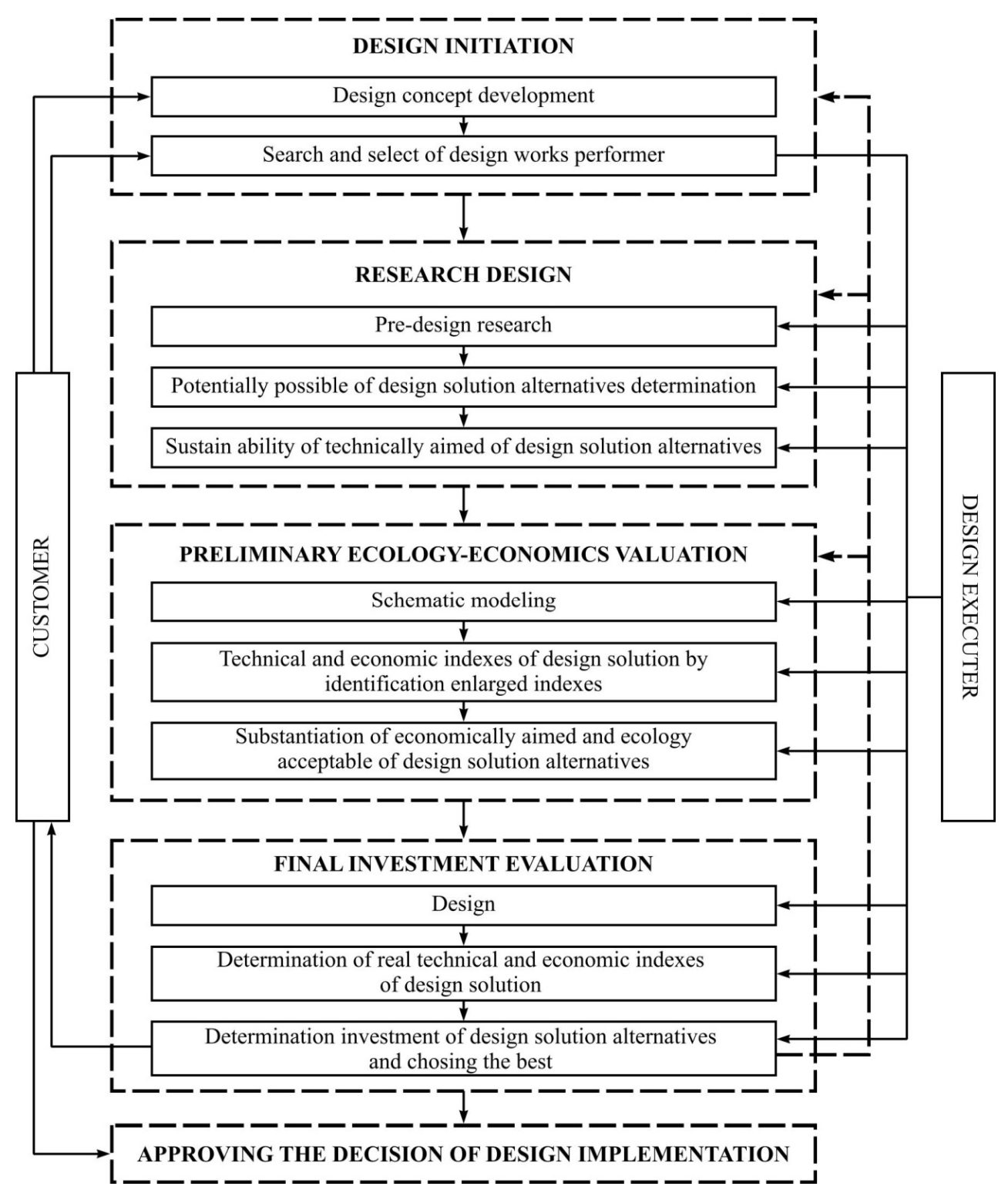

FIGURE 3. The general model of ecological and economic assessment reclamation project

of choosing the best one on the final stages of development. This forecasts, firstly, water regulation technology determination mostly suitable for implementation in terms of the goals and objectives of the project and in terms of the analysis of local conditions (climate, landscape, soil, geology, agronomy, etc.), availability and cost of raw materials, energy and labor. The results of the performed research determine all technologically possible at this object 'methods of mel- 
ioration and corresponding to them meliorative systems.

Variants of technical and technological solutions are composed of different water regulation technologies of reclaimed land and appropriate design solutions on reclamation systems and their technical elements. After all, water regulation technology (or methods) determines the necessary structural decisions as for the type of adjusting and central network, hydrotechnical stations, etc., and thus the type and design of meliorative system on reclaimed lands.

To substantiate optimal DS on a multivariate basis there is a need of chose for further conceptual design composed of a set of potential technical and technological solutions identified on the previous stage, the most suitable for implementation in production in natural and agroameliorative conditions of a real object. From a practical point of view their rational number may be 2-6 versions of DS. At this stage, options of DS for further research and evaluation can be selected on comprehensive criteria considering technical, technological and environmental conditions and restrictions on the use of expert opinion. The real interest from the number of possible water regulation schemes options primarily attract those which forecast water regulation on schemes when to all crops rotation the only one way of water regulation is used also on the scheme which is a combination of water regulation ways composed of optimal modes for each planned crop field 8 .

Previous environmental and economic assessment is carried out at the stage of feasibility study, which includes a schematic design and definition of technical and economic indicators for project options.

In general, schematic designs are preliminary plans of problem solution in specific conditions and usually, they cover the development of the major issues with a small number of indicators. Schematic design stage is developed for the conceptual definition of territorial requirements, functional, environmental object solutions, fundamental confirm the possibility and feasibility of creating it. At the stage of schematic design preliminary development is carried out and the main types and volumes of work for each of the alternatives DS analyzed are determined.

Subsequently, based on the schematic design, calculation of all required technical, technological, operational, environmental and economic parameters chosen to consider for draft options based on enlarged and standard indicators, including: power facility, the total number of employees, productivity, cost of major products, estimated cost of construction, cost of fixed assets, participation share of investors, annual demand for raw materials, energy, water, basic building materials costs, field area, used reclaimed lands directions and so on is done. These figures are output data for further economic evaluation and comparison of reclamation project alternatives.

After that, the comparative environmental and economic efficiency of the project developed variations and environmental conditions of comparable DS options is performed. Common approach to select the best DS in the field of land reclamation is focusing on their economic feasibility and environmental acceptability. 
From the set of pre-selected by the technical and technological parameters options for the project by environmental and economic criteria, choose one or more similar technical and economic indicators of environmentally acceptable for DS for their further more detailed development and evaluation.

For selected, in the previous stage, promising environmental and economic project option needed to acting requirements working documentation is developed, acceded constructional decisions and their technical parameters are clarified, the actual volume of the main construction and installation work, equipment, structures, material and energy needs, labor force, duration and the terms of construction works and others are determined.

So, transition to optimization design methods will help to improve the overall ecological and economic efficiency of drainage reclamation, especially in working out new construction, reconstruction and modernization of Irrigation and drainage systems.

\section{References}

Aydarov, I.P., Golovanov, A.I. \& Nikolsky, Y.N. (1990). Optimizatsiya meliorativnykh rezhimov oroshayemykh $i$ osushayemykh zemel' [Optimization of meliorative regimes of irrigated and drained agricultural land]. Moskva: Agrometeoizdat.

Juszczyk, M., Výskalab, M. \& Zima, K. (2015). Prospects for the use of BIM in Poland and the Czech Republic - Preliminary Research Result. Procedia Engineering, 123, 250-259.

Karuk, B.P. (1992). System approach to assessing the impact on the environment of drainage reclamation facilities in Ukraine. In Teoriya $i$ praktika ekologo-meliorativnogo monito- ringa $v$ Ukrainskom Poles'ye [Theory and practice of ecological and land reclamation monitoring in the Ukrainian Polesie] (pp. 22-32). Kyiv.

Mazhayskiy, Y., Rokochinskiy, A., Volchek, A., Meshyk, O. \& Jeznach, J. (ed.). (2017). Prirodoobustroystvo poles'ya [Environmental management of Polissya]. Ryazan: VNIIGiM of A. Kostiakov.

Mioduszewski, W., Kowalewski, Z., Zurawski, R. \& Stankiewicz, J. (2010). Drainage system in the Kampinos National Park. Journal of Water and Land Development, 14, 83-95.

Pierzgalski, E., Jeznach, J., Baryła, A., Brandyk, A., Stańczyk, T., Szejba, D. \& Wiśniewski, S. (2012). Weryfikacja systemów melioracyjnych pod katem znaczenia dla bezpieczeństwa powodziowego $w$ Regionie Wodnym Wisty Środkowej [The verification of drainage systems in terms of importance for flood safety]. Warszawa: Wydawnictwo SGGW:

Rahman, M.A., Suwal, S. \& Jäväjä, P. (2013). Diverse approach of BIM in AEC industry: a study of current knowledge and practice. In Proceedings of the 30th CIB W78 International Conference (pp. 79-88).

Rex, L.M. (1995). Sistemnyye issledovaniya meliorativnykh protsessov i sistem [System research of meliorative processes and systems]. Moskva: Aslan.

Rokochinskiy, A.M. (2010). Naukovi ta praktichni aspekti optimizaciï vodo regulyuvannya osushuvanikh zemel' na ekologo-ekonomichnikh zasadakh [The scientific and practical aspects optimization of water regulation drained lands on environmental and economic grounds]. Rivne: NUVGP.

Rokochynskiy, A.M. (2016). System optimization of water regulation on reclaimed lands. In V.G.Gusakov(ed.), Problemy ratsyonal'noho yspol'zovanyya pryrodnykh resursov y ustoychyvoe razvytye Poles'ya [Problems of rational use of natural resources and sustainable development of Polissya]. Vol. 2 (pp. 111-114). Minsk: Belaruskaya navuka.

Rokochynskiy, P., Volk, N., Frolenkova, N., Prykhodko, I., Gerasimov, O. \& Pinchuk, O. (2019). Evaluation of climate changes and their accounting for developing the reclamation measures in Western Ukraine. Scientific 
Review Engineering and Environmental Sciences, 28(1), 3-13.

Rokochinskiy, A., Volk, P., Pinchuk, O., Mendus, S., Koptyuk, R. (2017). Comparative evaluation of various approaches to the foundation of parameters of agricultural drainage. Journal of Water and Land Development, 34, 215-220.

Romashchenko, M.I., Sobko, O.O., Savchuk, D.P. \& Kulbida, M.I. (2003). Pro deyaki zavdannya ahrarnoyi nauky u zv"yazku zi zminamy klimatu. Naukova dopovid' - informatsiya [About some tasks of agricultural science in relation to climate change]. The scientific report - information. Kyiv: NAAS [Translated from Ukrainian].

SBS V. 2.4-1-99. Melioration systems and structures.

Shumakov, B.B. (1996). Melioration in the twenty-first century. Reclamation and Water Management, 3, 4-6.

\section{Summary}

Reclamation projects development
improvement technology considering op-
timization of drained lands water regula-
tion based on BIM. Improvement principles
of development reclamation projects technologies considering drained lands water regulation optimization based on BIM were observed. Modern methodological basis and at the same time, universal technical tool that allows to improve the practice of designing complex objects and systems that is successfully used and developed in almost all fields of science, technology and industry is computer aided design building information modelling - BIM. In structural terms BIM is an organizational and technical system consisting of a large number of interrelated and interacting components. The main function of BIM is to carry out object aided design and their components through the use of mathematical models and other automated design procedures and computer technology.
So, transition to optimization design methods will help to improve the overall ecological and economic efficiency of drainage reclamation, especially in working out new construction, reconstruction and modernization of irrigation and drainage systems.

\section{Author's address:}

Anatoliy Rokochinskiy

(https://orcid.org/0000-0002-5248-6394)

Pavlo Volk

(https://orcid.org/0000-0001-5736-8314)

Vasyl Turcheniuk

(https://orcid.org/0000-0002-1938-0344)

Roman Koptiuk

(https://orcid.org/0000-0002-7086-3608)

National University of Water and Environmental

Engineering

Institute of Water and Environmental Engineering

Department of Water Engineering and Water

Technology

Soborna 11, 330328 Rivne

Ukraine

e-mail: a.m.rokochinskiy@nuwm.edu.ua p.p.volk@nuwm.edu.ua v.o.turchenuk@nuwm.edu.ua r.m.koptyuk@nuwm.edu.ua

Jerzy Jeznach

(https://orcid.org/0000-0002-9719-0052)

Szkoła Główna Gospodarstwa Wiejskiego

w Warszawie

Wydział Budownictwa i Inżynierii Środowiska

ul. Nowoursynowska 159, 02-787 Warszawa

Poland

e-mail: jerzy_jeznach@sggw.pl

Nadia Frolenkova

(https://orcid.org/0000-0003-4553-9547)

National University of Water and Environmental

Engineering

Institute of Economics and Management

Department of Management

Soborna 11, 330328 Rivne

Ukraine

e-mail: n.a.frolenkova@nuwm.edu.ua 